\title{
Analysis of financial incentives as an instrument of renewable energy sources management in Montenegro
}

\author{
Boban Melovic ${ }^{1, *}$, Dragana Ćirović ${ }^{1}$ \\ ${ }^{1}$ University of Montenegro, 81000 Podgorica, Montenegro
}

\begin{abstract}
This article analyzes the effects of financial incentives implemented in Montenegro, with the aim of increasing the exploitation rate of renewable energy sources on the consumption side. Those incentives were mostly focused on households. They made it easier to obtain the funds for installing the equipment necessary for the use of solar energy and biomass, as the main energy sources, for the needs of individual households. The results show that the implemented measures had smaller effects than expected and that the interest of inhabitants for the use of renewable energy sources is still at low level. The reason for such a situation is an insufficiently developed awareness of their importance and lack of information about the way that the systems used for their exploitation work and all the benefits that those systems offer. Occasional promotional activities, carried out during the implementation of the measures mentioned above, weren't sufficiently effective. Therefore, a continuous effort must be invested in the forthcoming period, in order to inform and educate citizens, so that the energy potentials of Montenegro could be used in a right way.
\end{abstract}

\section{Introduction}

Non-rational usage of non-renewable energy sources, as well as numerous harmful effects which industrial development most of the countries had on the environment, has led to the emergence of sustainable development concept. Sustainable development, which implies meeting the needs of present generations without compromising the ability of future generations to fulfill their own [1], is based on the usage of renewable energy sources and environmental protection as the basic prerequisites for achieving social well-being. Bearing in mind the fact that the energy sector forms the basis of the functioning of all other activities, its sustainability is imposed as a necessary condition for achieving sustainable development of the entire economy. In order to meet this requirement, there has been created a framework of four main principles, as the basis for future energy sector development efforts for most of the countries in the world: the change of existing ways of using energy, the adoption of advanced tehnologies of energy production and distribution, the usage of renewable energy sources as an alternative to conventional production methods

*Corresponding author: bobanm@ucg.ac.me 
in order to reduce negative external influences and further development of centralized systems for production and transmission of so-called clean energy [2]. The application of these principles should provide gradual shift from traditional production methods to clean energy production, which emphasize the importance of renewable energy sources and development of tehnologies needed for its efficient exploitation.

Renewable energy sources (RES) are natural sources (solar energy, wind power, biomass, geothermal energy etc.) which are constantly being suplemented by ongoing natural processes, and therefore enable unhindered energy production to be carried out in an environmentally friendly manner [3]. The efficient usage of these sources would be helpfull in solving many problems that most of the countries are facing with, giving benefits such as: greater reliability of energy suplying, employment of local population, environmental protection and the development of rural areas which would prevent further migration of the population into urban areas [4-6]. In addition, the renewable energy sources development would enable GDP growth (through investments, new jobs, taxes etc.), poverty reduction (making it possible for rural areas to develop indipendently, based on its own natural resources) and growth od living standards through better access to lighting, heating and cooling services, which are necessary for unhindered functioning of social communities [3].

It should be borne in mind that intensive usage of RES also has some disadvantages, which are reflected in high costs of installation of the necessary tehnology, increased noise level and changed appearance of the landscapes and individual objects [1,5]. However, taking into consideration the fact that energy production is the main factor of economic growth and prosperity, and all the negative effects that traditional sources have on the environment, these disadvantages are certainly negligible.

Although most of countries in the world have recognized the importance of these sources, the degree of their utilization is still small due to the numerous barriers that occur in the process of their exploitation. Economic and institutional barriers are related to high investment costs compared to the costs of using traditional fuels, lack of financial incentives, inefficiencies in the existing legal framework, bureaucratic problems and complexity of licensing process. Technical and planning barriers are mostly related to the inadequate geographical features of particular areas, the problems conected to the selection of the location at which the technology necessary for the exploitation of the mentioned sources will be installed and the problems of inadequate funds planning. Also, barriers that arise from the negative public perception caused by a lack of knowledge about new technologies, mistrust or a doubt about the real intentions of investors, shouldn't be neglected [6]. Most of these barriers referes to the construction of large capacities, which should be able to provde the required amount of energy needed for a large number of facilities. However, the number of potential barriers is much lower in the case of implementation of tehnologies needed for usage of renewable energy sources in individual households (primarly for use of solar energy and biomass). Such a solution is particularly suitable for small countries such as Montenegro, especially in rural areas with relatively small number of households, which are insufficiently connected due to poorly developed infrastructure. The main problem that arises in that case are too high initial investments and that problem is often amplified by the insufficient information that end-users have. Therefore it is necessary to know the public perception about RES and the factors that influence their willingness to pay higher prices when using them, in order to eliminate these barriers. Researches show that those consumers who are more concerned about climate changes and environmental threats express greater willingness to pay higher prices for energy that comes from renewable sources [7]. Besides of that, the willingness to pay higher energy prices is also positively influenced by the increase of income of individuals. Observed trough socioeconomic qualities, those consumers who are educated, have a higher level of income, are members of ecological associations or possess sufficient knowledge 
about the importance of environmental protection, and have problems with regular supply of necessary quantities of energy, express greater willingness to pay more prices or invest in the exploitation of renewable energy sources [6]. This emphasizes the importance of adequate promotional campaigns aimed at educating and informing end-users, in order to remove all barriers which ocur during the process of using RES potentials.

\section{Management of renewable energy sources in Montenegro.}

One of the main problems in Montenegro in the field of energy is the high degree of inefficiency (domestic energy consumption per GDP unit is two and a half times higher than the average of the EU countries), which is why in the forthcoming period special attention must be paid to analyzing and eliminating the causes of this kind of state [8]. This problem is particularly pronounced in the area of electricity supply, where Montenegro appears as an importer, despite the fact that with the adequate valorization of its own potential, it could produce energy in quantities that fully meet its own needs [9]. The data about energy imablance in this country is given in the Table 1 [10].

Table 1. Electricity consumtion in Montenegro.

\begin{tabular}{|l|c|c|c|}
\hline Electricity & Total & $\begin{array}{c}\text { Montenegro per } \\
\text { capita }\end{array}$ & $\begin{array}{c}\text { Compared to Erupe } \\
\text { per capita }\end{array}$ \\
\hline Own consumption & $2.81 \mathrm{bn} \mathrm{kWh}$ & $4,511.97 \mathrm{kWh}$ & $5,510.65 \mathrm{kWh}$ \\
\hline Production & $3.05 \mathrm{bn} \mathrm{kWh}$ & $4,892.78 \mathrm{kWh}$ & $5,924.84 \mathrm{kWh}$ \\
\hline Import & $1.21 \mathrm{bn} \mathrm{kWh}$ & $1,944.26 \mathrm{kWh}$ & $729.88 \mathrm{kWh}$ \\
\hline Export & $914.00 \mathrm{~m} \mathrm{kWh}$ & $1,468.64 \mathrm{kWh}$ & $707.80 \mathrm{kWh}$ \\
\hline
\end{tabular}

Therefore, special attention is paid to the possibilities of exploitation of renewable energy sources, as an integral part of the overall economic development strategy based on sustainable grounds. Because of its specific geographical position, Montenegro has a great potential to use RES, which primarily relates to solar energy, hydropower, wind and biomass. The analysis of maximal production capacities (given in the Table 2) shows that Montenegro has the potential to provide itself completely with self-produced renewable energy, dominantly using especially using hydropower [10].

Table 2. Production capacities in Montenegro per energy source.

\begin{tabular}{|l|c|c|c|c|c|}
\hline $\begin{array}{l}\text { Energy } \\
\text { source }\end{array}$ & $\begin{array}{c}\text { Total in } \\
\text { Montenegro }\end{array}$ & $\begin{array}{c}\text { Percentage in } \\
\text { Montenegro }\end{array}$ & $\begin{array}{c}\text { Percentage } \\
\text { in Europe }\end{array}$ & $\begin{array}{c}\text { Per capita in } \\
\text { Montenegro }\end{array}$ & $\begin{array}{c}\text { Per capita in } \\
\text { Eruope }\end{array}$ \\
\hline Fosil fuels & $1.79 \mathrm{bn} \mathrm{kWh}$ & $23.0 \%$ & $42.2 \%$ & $2,881.32 \mathrm{kWh}$ & $\begin{array}{c}8,114.79 \\
\mathrm{kWh}\end{array}$ \\
\hline $\begin{array}{l}\text { Nuclear } \\
\text { power }\end{array}$ & $0.00 \mathrm{kWh}$ & $0.0 \%$ & $7.0 \%$ & $0.00 \mathrm{kWh}$ & $\begin{array}{c}1,154.21 \\
\mathrm{kWh} 3,976.91 \\
\mathrm{kWh}\end{array}$ \\
\hline $\begin{array}{l}\text { Water } \\
\text { power }\end{array}$ & $5.38 \mathrm{bn} \mathrm{kWh}$ & $69.0 \%$ & $24.1 \%$ & $8,643.95 \mathrm{kWh}$ & $3,976.91 \mathrm{kWh}$ \\
\hline $\begin{array}{l}\text { Renewable } \\
\text { energy }\end{array}$ & $\begin{array}{c}623.71 \mathrm{~m} \\
\mathrm{kWh}\end{array}$ & $8.0 \%$ & $19.7 \%$ & $1,002.20 \mathrm{kWh}$ & $3,274.18 \mathrm{kWh}$ \\
\hline $\begin{array}{l}\text { Total } \\
\text { production } \\
\text { capacity }\end{array}$ & $7.80 \mathrm{bn} \mathrm{kWh}$ & $100.0 \%$ & $100.0 \%$ & $12,527.46 \mathrm{kWh}$ & $\begin{array}{l}16,488.68 \\
3,274.18 \mathrm{kWh}\end{array}$ \\
\hline
\end{tabular}

The national target of the RES share in gross final energy consumption by 2020 is $33 \%$. Montenegro has accomplished this goal, mainly relying on the production of hydropower [25]. However, the degree of utilization of hydro potential is only $20 \%$, while the degree of 
utilization of wind and solar energy is much lower [12-14]. Wind power is used partly trough the construction of windmills in Krnovo, while the degree of solar energy utilization is negligible and is related to the construction of solar panels in a relatively small number of households, which is realized through the projects Montesol and Solar Panels [12, 15].

Considering the fact that the national target for the RES share by 2020 has already been fulfilled, and the importance of their valorization for the overall economic development of Montenegro, new goals have been defined and are needed to be achieved by $2022[16,17]$ :

- Growth in renewable energy production up to $42 \%$ in the area of final consumption,

- Reduced import deficit in the field of energy through increasing the level of RES utilization and stimulation of the final consumers to produce electricity themselves,

- Promotion of the research and new technologies implementation in order to reduce environmental pollution,

- Increasement of energy efficiency through the increased utilization of RES for energy supply of residential buildings, enterprises and public institutions,

- Increasement of the utilization of RES in other activities, especially in the area of public transport and tourism.

In order to achieve these objectives, a numerous measures have been adopted, which mostly refers to the adjustment of the legal framework and law adoption. Additional measures have been addopted to provide financial incentives in order to increase the use of RES in final consumption. Most of these measures represesent continuation of the implementation of mechanisms that have been applied over the past several years, and are dominantly related to financial incentives aimed at increasing the energy efficiency in buildings and public institutions, and encouraging the appropriate technology application in order to increase the usage of solar energy and biomass in individual households [15]. The funds needed for the implementation of these measures are provided through the access to European fonds and trough the support of the European Bank, as well as from certain fees for renewable resources that are paid by all electricity consumers $[15,18]$.

However, despite the efforts that have been made so far, there are still a numerous barriers that prevent the intensified use of RES. Besides of a higher prices, the main problem are complex bureaucratic procedures that implie the division of jurisdictions between several institutions, which causes uncoordinated work. Also, greater involvement of local communities in the process of planning and capacity building is needed in order to increase the usage of RES, as well as better training of the personnel involved in that process $[16,19]$. Of course, there are also many other challenges that managers and other decision makers face in today's business environment, especially in the field of engineering management [20] which aslo affects the area of RES. That is why the issue of business logistics [21] is of great importance for decision making in energy sector. The analysis of these barriers provides a signal at which direction the future efforts should be oriented, so that the energy potentials of Montenegro could be exploited.

\section{Financial incentives as an instrument of RES management in Montenegro}

In order to increase the level of usage of RES in final consumption in Montenegro, three projects based on financial incentives have been implemented over the past several years: Montesol, Solarni katuni and Energy wood. The Montesol project was aimed to provide loans for households, which is needed for the installation of solar collectors, that would enable them to produce energy for their own needs. It was realized in cooperation with the United Nations Environment Program (UNEP) and the Italian Ministry of Environment, Land and Sea (IMELS) in 2011, and the total budget for its implementation was $\$ 848670$ 
(\$750 000 for interest rate subsidy, $\$ 40000$ for promotion, $\$ 10000$ for management costs and $\$ 48670$ for partners' capacity building - distributors and banks) [22-24]. This project enabled households to receive interest-free loans from partner banks for the installation of solar collectors. At the beginning of the project there were granted loans in the amount of $1350 €, 1800 €$ and $2250 €$, with a repayment period of 3,5 and 7 years. However, it was confirmed that such a mechanism still represented a barrier to a certain number of citizens, which is why it was improved afterwards, in a way that the maximum amount of loans was increased up to $5000 €$ and there was introduced a flexible repayment period of 7 years. It was planned for the project to be implemented util August 2012. but the intended funds weren't spend by then, so it was decided that the period of its realization should be extended by the end of a year 2013 [22-24]. In order to educate and raise citizens' awareness about the significance of this project and the benefits it offers, promotion activities were implemented via electronic and printed media, and an educational TV spot was made. However, despite significant financial incentives offered by this project and promotional activities that were carried out, a small number of households decided to install solar collectors (about 140). The main reasons for insufficient interest were lack of information and insufficiently developed citizens' awareness about the energy efficiency. Additional problems were their low purchasing power and credit indebtedness. Considering that only $35 \%$ of the funds were spent within the planned deadline, it was decidet to extend the project to a certain number of legal entities from the tourism sector (with the maximum amount of approved loans up to $50000 €$ ). However, the project was suspended before the planned expansion was introduced [22-24].

The Solarni Katuni project was realized within the cooperation between the Ministry of Economy and the Ministry of Agriculture and Rural Development, with the support of local government units in the north of the country. The goal of this project was to provide financial means for the installation of solar systems in households in the areas that aren't connected to electrical network. The project organizers were responsible for $70 \%$ of total costs, while the final users were responsible for the remaining $30 \%$ of the costs $[25,26]$. Therefore the problems of supplying these areas with electricity are solved, and the energy produced this way was free for end users. This significantly improved the living conditions for the members of households, and at the same time it represented one of the incentive measures in the field of agriculture, as one of the priority sectors in Montenegro. The Solarni katuni project was realized three times. For its implementation in 2011 there were provided funds in the amount of $87500 €$, in 2012 funds in the amount of $84400 €$, and in 2017 funds in the amount of $55000 €[24-26]$. The project was very successful and, thanks to it, the solar systems were built in about 240 households [25, 26].

The Energy wood project was implemented in order to provide a favourable loans for household, aimed at installing heating systems based on the use of biomass. It was conceived similar to Montesol. It was conducted on three occasions: in 2013 in cooperation with luxembourg development cooperation agency called Lux-Development, in 2015 with the support of the Government of the Kingdom of Norway and in 2017 [24]. Implementation of this project was supposed to provide: reduction of interest rates for loans aimed at household, risk reduction for financial institutions when entering the new market segment, encourage partnerships between commercial banks and distributors of biomass heating equipment, and reduce the total harmful gases emissions. Within this project from 2013 , interested citizens were entitled to get interest-free loans in the amount of $€ 3500 €$ for installing heating systems that use modern forms of biomass, with a repayment period of 5 years. The total budget allocated for its implementation amounted to $130000 €$ [23, 24]. In order to improve the visibility of the project, promotional activities were carried out through participation in the Energy Fair in Budva in 2013, and through commercial advertising that was broadcasted on eight radio stations, five times a day, from November 
2013 to January 2014 [23]. The lending conditions in phases II and III of the project remained unchanged, with budget of $240000 €$ being spent under phase II, and $85000 €$ planned for the phase III which is still in progress [24].

Within the first two phases of the project 532 loans were approved. Apart from the fact that a certain number of households introduced modern and environmentally-friendly heating systems, the implementation of this project has also positively influenced the montenegrin market of the heating technologies, which is especially important for distributors of this type of equipment. Therefore, overall project has been characterized as successful [27].

The analysis of the final effects of all these projects shows that Solarni katuni produced the largest response of citizens. However, this is understandable for several reasons. First of all, this project was designed in order to provide electricity supply for households in the areas that previously haven't been connected to the electrical network. Therefore, the installation of solar systems was the only way to provide the necessary amount of energy, wich is needed for unhindered functioning of households in these areas. Furthermore, the project organizers paid about $70 \%$ of total costs of procurement, transport and equipment installation, so the financial risk of households was reduced to a minimum. Considering the aforementioned facts, the importance of prior citizens' awareness about the reliability of solar systems and the way in which they operate, as well as the importance of their awareness about environmental protection, was quite small. Therefore, it didn't have a significant imapct on making the final decision. However, the situation within the other two projects (Montesol and Energy wood) was different. First of all, financial incentives were lower and covered only the cost of interest rates on loans which were approved for the installation of appropriate systems. Hence, the households had the obligation to repay the taken loan, which is why the financial risk of installing new energy production systems significantly increased. Additionally, it is about households that have already been connected to the electricity network and didn't have major problems in the process of energy supply, so the incentives for using new energy sources were much lower. Considering the higher prices of pellet and other forms of biomass (compared to the prices of traditional sources), which is being paid by end users, it is clear that education and information play a crucial role in making the final decision by consumers. Bearing in mind that promotional activities, aimed at educating users about the characteristics and benefits of using RES in final consumption, were carried out only occasionally during the implementation of the above mentioned projects, it is understandable that they did not have the expected results. Therefore, in the forthcoming period, continuous efforts must be made in order to increase the awareness of citizens about the importance of environmental protection and all the benefits that use of RES in final consumption creates for individual users, as well as for the society as a whole. Only in that way all prerequisites needed for utilizing the full energy potential of Montenegro will be met.

\section{Conclusion}

A high degree of energy efficiency is one of the cornerstones of economic development. The future economic development of any country, including Montenegro, must be established on a sustainable basis, which is why the importance of using renewable energy sources becomes emphasized. However, their adequate valorization involves the application and transfer of new technologies, both at macro and micro level. Montenegro, thanks to its specific geographical position and natural resources, is characterized by significant potential in terms of RES. However, the degree of their usage is still at a relatively low level and mostly refers to the use of hydro-potential and partly wind energy, while the degree of utilization of solar energy and biomass is almost negligible (compared to existing 
potencials). Therefore, in the past few years, certain efforts have been made in order to increase the share of RES in total energy consumption. Most of these efforts are invested at macro level and refers to adaptation of the legal framework, through the adoption of a series of laws, and through the simplification of bureaucratic procedures. Efforts made at micro level were supposed to provide financial incentives for end users, in order to encourage them to install systems that enable the production and use of energy from renewable sources within individual households. These financial incentives gave certain results, but less than expected. The main reason for their insufficient efficiency is lack of information about the characteristics and benefits of modern systems for RES use, as well as insufficiently developed awareness of citizens about the importance of environmental protection. Occasional promotional activities that were carried out during the implementation of financial incentives weren't sufficient, and therefore continuous efforts must be made in order to inform and educate end users. This will fulfill one of the basic assumptions for the efficient use of all the RES potentials that Montenegro has at its disposal.

\section{References}

1. http://www.sd-commission.org.uk/pages/what-is-sustainable-development.html official website of Commision on Sustainable Development

2. R. Kothari, V. V. Tyagi, A. Pathak, Renewable and Sustainable Energy Reviews 14(9), 3164-3170 (2010).

3. https://www.nrdc.org/stories/renewable-energy-clean-facts\#sec-whatis - official website of association NRDC (Natural Resources Defense Council)

4. O. Edenhofer, L. Hirth, B. Knopf, M. Pahle, S. Schlömer, E. Schmid, F. Ueckerdt, Energy Economics 40, S12-S23 (2013).

5. N. L. Panwar, S. C. Kaushik, S. Kothari, Renewable and Sustainable Energy Reviews 15(3), 1513-1524 (2011).

6. E. K. Stigka, J. A. Paravantis, G. K. Mihalakakou, Renewable and sustainable energy Reviews, 32, 100-106 (2014).

7. N. Zografakis, E. Sifaki, M. Pagalou, G. Nikitaki, V. Psarakis, K. P. Tsagarakis, Renewable and sustainable energy reviews 14(3), 1088-1095 (2010).

8. S. Popovic, Benefits from the resource efficiency and prospects of Montenegro's green growth (Friedrich Ebert Stiftung, Belgrade, 2017).

9. https://bankwatch.org/beyond-coal/the-energy-sector-in-montenegro - official website of the organization Bankwatch Network

10. https://www.worlddata.info/europe/montenegro/energy-consumption.php - official website of World Data project.

11. http://www.obnovljivi.com/hrvatska-i-regija/3513-vlada-crna-gore-usvojila-izvjestaj-oobnovljivim-izvorima-energije - website of internet portal Obnovljivi.com

12. Ministry for Environment, Land and Sea of the Republic of Italy. Assessment of the potential of renewable energy sources in the Republic of Montenegro (CETMA, 2007).

13. Government of Montenegro. Projects in the energy sector (MIPA, Podgorica, 2013).

14. https://www.export.gov/article?id=Montenegro-energy-sector - official website of the organization Export.gov 
15. Ministry of Economy of Montenegro. Report on the implementation of the National Action Plan for the use of energy from renewable sources by 2020, for the period 2014 - 2015 (Podgorica, 2015).

16. Ministry of Science of Montenegro. Renewable energy sources - results of entrepreneurial discovery process (Podgorica, 2018).

17. Government of Montenegro. National Action Plan in the area of renewable energy sources by 2020. (Podgorica, 2018).

18. Ministry of Economy of Montenegro. Energy Development Strategy of Montenegro until 2030 - Action Plan 2016 - 2020 (Podgorica, 2015).

19. Energy Community Secreteriat. Annual implementation report 2016/2017 (2017).

20. S. Mitrović, B. Melović, Challenges for management engineers in modern business environment. Challenges for the Future - Engineering Management, monograph, 165179 (2013).

21. B. Melović, S. Mitrović, Business logistics as a factor determining modern engineering management. XVI International Scientific Conference on Industrial Systems (IS'14), 247-252 (2014).

22. Ministry of Economy of Montenegro. Information on the implementation of the Montesol project.(Podgorica, 2015).

23. Ministry of Economy of Montenegro. Report on the implementation of projects for providing incentives for the use of renewable energy sources on the consumption side (Podgorica, 2015).

24. https://www.energetska-efikasnost.me/ee.php?id=27 - official website designed for projects in the field of energy efficiency in Montenegro

25. Government of Montenegro. Report on the implementation of the Energy Efficiency Action Plan of Montenegro 2016-2018 for year 2017 (Podgorica, 2017).

26. https://balkangreenenergynews.com/rs/pocinje-treca-faza-projekta-solarni-katuni-biceugradena-54-fotonaponska-sistema/ - official website of internet portal Balkan Green Energy News.

27. https://www.energetskaefikasnost.me/uploads/file/Tekstovi/Energy\%20wood_brosura_CG_final.pdf - link of publication about the results of the second phase of the Energy Wood project 